\title{
Pprevalence and antibiotic resistance profile of bacterial isolates from wounds in burn unit and a nearby trauma ward at Ramathibodi Hopsital, Bangkok, Thailand
}

\author{
S Srisangkaew*, A Boonnark, M Kunakorn, P Santanirand \\ From International Conference on Prevention \& Infection Control (ICPIC 2011) \\ Geneva, Switzerland. 29 June - 2 July 2011
}

\section{Introduction / objectives}

Data analysis of prevalence and antibiotic resistance profile of bacterial isolates from the particular wards could lead to an improvement of treatment, control and prevention of infection in the units. The aim of this study is to evaluate predominant bacterial isolates from the Burn Unit (BU) and a nearby trauma ward (TW) in Ramathibodi hospital, Bangkok, Thailand.

\section{Methods}

A five-year retrospective review of wound cultures from patients who admitted at BU and a nearby TW, Ramathibodi hospital was performed.

\section{Results}

The highest prevalence Gram-negative and Gram-positive bacteria in both wards were similar as Pseudomonas aeruginosa (20.99 and 15.17\%) and Staphylococcus aureus (13.12 and 12.16\%), respectively. Although the prevalence of multiple drug resistant (MDR) strains of Acinetobacter baumannii showed no differrence (59.09 vs $60.53 \%$ ) in both wards, the prevelence of MDR P. aeruginosa and methicillin-resistant $S$. aureus (MRSA) in BU was higher than TW ( 15.28 vs $6.25 \%$ and 66.67 vs $51.95 \%$, respectively). In contrast, the prevalence of E. coli and Enterobacter spp. isolated from TW was higher than BU whereas the second common Gram-positive organism was Enterococcus spp. in both wards.

Department of pathology, Ramathibodi Hospital, Mahidol University, Bangkok, Thailand

\section{Conclusion}

Not only high incidence of bacterial infection but also high prevalence of MDR strains in Burn Unit has become another challenge for medical staff as well as those who involve in hospital infection control program to be seriously concerned.

\section{Disclosure of interest}

None declared.

Published: 29 June 2011

doi:10.1186/1753-6561-5-S6-P230

Cite this article as: Srisangkaew et al:: Pprevalence and antibiotic resistance profile of bacterial isolates from wounds in burn unit and a nearby trauma ward at Ramathibodi Hopsital, Bangkok, Thailand. BMC Proceedings 2011 5(Suppl 6):P230.

Submit your next manuscript to BioMed Central and take full advantage of:

- Convenient online submission

- Thorough peer review

- No space constraints or color figure charges

- Immediate publication on acceptance

- Inclusion in PubMed, CAS, Scopus and Google Scholar

- Research which is freely available for redistribution

Submit your manuscript at www.biomedcentral.com/submit
() Biomed Central

\section{Biomed Central}

(c) 2011 Srisangkaew et al; licensee BioMed Central Ltd. This is an open access article distributed under the terms of the Creative Commons Attribution License (http://creativecommons.org/licenses/by/2.0), which permits unrestricted use, distribution, and reproduction in any medium, provided the original work is properly cited. 